\title{
A MORALITY OF MENDACITY: THE SOUTHERN ARISTOCRATIC CODE OF HONOR IN TENNESSEE WILLIAMS'S A CAT ON A HOT TIN ROOF
}

CATHERINE FERRANTE

ennessee Williams's $A$ Cat on a Hot Tin Roof, set on a 1950s Mississippi
plantation owned by a man called Big Daddy, remains connected to many of
the vestiges of the strict yet decaying unwritten moral of code of the Antebellum Era's Old South. This code includes a false sense of honor, reputation, prestige, power, progeny and repression. Big Daddy's younger son, Brick Pollitt, a product of this system, is an alcoholic homophobe who seems incapable of coping with his best friend's confession of homosexuality and subsequent death. Maggie, Brick's wife, is trying to re-establish her relationship with her husband, who blames her for his friend's death, and is desperately trying to secure power for herself within this flawed family system.

Brick spends all three acts of the play, just one evening on the Pollitt family plantation, drinking, trying to drink, or trying to avoid talking about why he drinks. He is filled with "disgust" because of all the "mendacity," or lies, in the world around him, and he feels that he is a truthful man surrounded by liars and schemers (Williams 107-108). However, the term "mendacity" vibrates through $A$ Cat on a Hot Tin Roof not only as a charge against the web of lies the Pollitt family tells each other, but also as an accusation of the self-deception the main characters tell themselves in order to maintain the patriarchal, white supremacist plantation system. The characters of Brick, Big Daddy, and Maggie all demand that they tell each other the truth, but that is never a simple proposition, especially when repression of the truth maintains the crumbling façade of the merit of plantation life. In order to maintain their way of life, Big Daddy and Maggie manipulate truth in their own way and for their own purposes. However, both characters are subordinate to the main character, Brick, who, once confronted with the mendacity of the world he lives in, struggles to recognize that manipulation of truth is inherent to the society he cherishes. Furthermore, he refuses to recognize how he himself has repressed truth for his own purposes.

As a result, as Brick is forced to engage with his family, the various internal issues causing his existential crisis become apparent; he is crippled by the very system that has kept him from understanding himself. In order to understand Brick better than he understands himself, this paper explores the sources of his crisis and the society that is pressuring him to fulfill his responsibilities as a son, husband, and heir in a system fraught with mendacity. This includes examining the code of honor that defined the Southern aristocracy and the system of power it maintained through the Reconstruction era as well as interrogating Brick's values and actions as he wrestles

Meliora Vol. 1, Issue 1 
with the complexities and contradictions within that system. These values and actions include his homophobia and the pressures placed upon him by the Southern aristocracy - represented by the persons of Big Daddy and Maggie- to recover from his apparent crisis and inability to participate within their family system. This paper argues that Brick's passive complacency is as violent as his family's active maintenance of the plantation.

\section{The Southern Aristocratic Code of Honor vs. True Honor}

To understand the substructure of the play and its characters requires a clear insight into the strict, unwritten code that dominated the Old South, which still haunts the characters of the play one hundred years later. Historian Bertram WyattBrown carefully details the fabric of the Old South in his book Southern Honor: Ethics and Behavior in the Old South. Wyatt-Brown claims that the core value of the Southern aristocracy was honor; however, the particular variety of honor that ruled the Old South was one that valued power, prestige, and progeny as tools for the perpetuation of the plantation system. While the Old South claimed that their values aligned with that of "true honor: the unity of the inner virtue with the natural order of reason, the innate desire of man for the good and the happy congruence of inner virtue with outward public action," their actions reveal that their values were not so simple (Wyatt-Brown 22).

In the Antebellum system, honor itself became "defective," relying on shame, public opinion, and reputation. Honor became rooted in a culture of reputation and outward appearances, leaving many Southerners "in shackles of prejudice, pride and superficiality" (Wyatt-Brown 22). Since honor was accorded on the basis of informal community decision, there were "rules of behavior... that were not rules, not immutable or even logical. At best they were options... that provided a means of strict human choices... It established signposts of appropriate conduct. In this way honor gave meaning to lives, not as a myth but as a vital code" (WyattBrown 114). This system was fraught with inner contradictions: "The chief problem was the discrepancy between honor as obedience to superiors and the contrary duty to achieve a place for oneself and family" (Wyatt-Brown 61). The latter, self-serving honor created space for violence and betrayal to be somehow construed as honorable. For example, slavery could be tolerated and encouraged in a very Christian, famously hospitable society because slavery supported the system that gave these men honor, power, prestige and reputation. Wyatt-Brown claims "not conscience, but shame, not guilt, were the psychological and social underpinnings of the Southern culture" (22). Thus, unless an action was reprimanded with social shame, there were no repercussions regarding one's honor. While guilt recognizes that an action is wrong, shame requires conformity to community expectations and

deep repression of the self. In $A$ Cat on a Hot Tin Roof, this contrast between shame

Meliora Vol. 1, Issue 1 
and guilt becomes significant. William Faulkner, a Southern writer who, like Williams, was concerned with portraying the idiosyncrasies of the Southern aristocracy, calls this repression of self-knowledge "innocence" because it keeps a person in an immature state, unwilling and unable to critically evaluate actions as right or wrong (Faulkner qtd. by Wyatt-Brown 153).

While the Southern code of honor complicates a man's relationship to himself, it also affected how individuals related to each other. The Southern moral system, based on honor and reputation, is also reflected in the attitude of men and women towards each other. Within relationships between white men, the Southern ethical code dictated that "all white men were brothers" despite differences in education or other social advantages. Therefore, each white man was "dependent upon the esteem of the others and acted accordingly," creating a camaraderie among white men (Wyatt-Brown 69). Women were required to produce heirs, but they were also feared. A woman, however, had the power to publicly shame her husband or other men by casting doubt on any sexual inabilities or lack of moral righteousness (Wyatt-Brown 52). In this way, a woman had the ability to ruin men's reputations. Therefore, as a woman's only social power in her relationships with men rested in her sexuality, her ability or inability to have children was either a source of security or shame. As a result of men's dual fear of and reliance on the sexual woman, marriages could suffer from a man's struggle "over which would be the greater commitment, the husband's loyalty to male friends or to his wife" (Wyatt-Brown 278). The relationships between Brick, Maggie, and Skipper, to be explored in detail, are representative of this tension. Together, the variant but connected demands of the external social system, described above, on the interior family structure of the Pollitt family is the foundation of Brick's world.

\section{Big Daddy and Maggie as the Contradictory Southern Aristocracy}

Applying this social system to the Pollitt family plantation, the characters who are most successful at attaining their personal goals within this Southern world are those willing to accept the seemingly incongruent contradictions between true honor and the reality of the Southern plantation system. These contradictions are perhaps what Brick calls "mendacity," noting his disgust that lies and contradictions are often the foundation of the "system that we live in" (Williams 129). Big Daddy and Maggie, however, adhere to a more self-serving concept of honor, attempting to avoid public shame without much regard for their guilt. Exploring the ways in which these two characters represent the success within this defective honor system is integral to exploring Brick's adamant reaction against it. Additionally, exploring Big Daddy and Maggie as representatives of the moral flaws of the contradictory system of honor that ruled the Southern Aristocracy proves that, while Brick clings to the 
ideal of true honor, the defective honor underneath the Southern façade has been in effect for Brick's entire life.

Big Daddy, for example, represents the complex and contradictory nature of the Southern aristocracy, as he is actively perpetuating a system of white supremacy while believing in the authority of his moral code. The Pollitt family's large fortune relies on the labor of Black people, who are mostly ignored throughout the play by its characters. The subjugation of Black people, as stated above by Wyatt, seems theoretically contradictory to a system of honor, but is, in fact, fundamental to it. Michael P. Bibler brings attention to what he calls "the most telling racial intrusion in the play," which takes place in Act Two "when Brick tells Big Daddy that the doctor has lied and that he really does have an incurable case of cancer:"

At that precise moment, Big Daddy "swings out onto the gallery" and the black servants again offer their disembodied voices in a song that undeniably evokes the sentiment of the Old South: "Pick a Bale of Cotton." Simultaneously, Mae comes rushing into the room shouting, "Oh, Big Daddy, the field-hands are singin' fo' you!" (p. 94). Big Daddy has tried to depict himself as the voice of tolerance, but the play contradicts him with a dose of reality by revealing the continued subordination of African Americans on his own plantation-a dose of reality especially poignant at the moment when Big Daddy also has to confront the reality of his own death...the play forces the audience to recognize that the plantation economy still depends on the exploitation of black labor even a century after the abolition of slavery. (Bibler 388)

As Bibler describes, Big Daddy's claims of tolerance are juxtaposed with his continued perpetration of this violently oppressive system. The very fact that the setting is a plantation at all, that the plantation system is still thriving even in a modified way, signals to the audience that the world in which Brick is living is one of tradition, hierarchy, and white supremacy. Although Williams is telling Brick's story, one in which the servants of the house are never explicitly acknowledged by the white characters but are always there, he intentionally brings them into the periphery of the story, reminding his audience of the influences of the Old South on the Pollitt family's way of life. Additionally, the traditional plantation system of the Old South of the Antebellum era relied on white men maintaining their economic and social power through patrilineal inheritance. Thus, it follows that the white men in power also needed to be heterosexual, or at least participate in heterosexual acts, in order to produce heirs. Thus, it is not surprising that Brick's older brother, Gooper, and his wife, Mae, reflect the power struggle to produce an heir that is embedded in the Old South's economic system.

The contradictions present within Big Daddy's plantation are both reminiscent of the Antebellum aristocracy and modern in their own way; this plantation is both a relic of the Old South and a contrast to it. Bibler is adamant that 
"though it may look antebellum, Big Daddy's plantation is remarkably contemporary to its times, and should by no means be mistaken as a historical or ideological anachronism" (Bibler 384). Arguably the most important difference between the Old Southern plantation and this one is that Big Daddy's plantation is a relatively new one. In fact, the plantation is part of a newer wave of plantations, which were built after the Reconstruction Era, by the previous owners, Jack Straw and Peter Ochello. Williams comments in his Notes for the Designer that even "the style of [Straw and Ochello's] room is not what you would expect in the home of the Delta's biggest cotton-planter. It is Victorian with a touch of the Far East. It hasn't changed much since it was occupied by the original owners of the place" (Williams 15). Thus, in both form and content, this specific plantation is markedly different to the plantations of the Old South. The blend of various different aesthetic styles in the room illustrates the way that Straw and Ochello used the space of the plantation to break boundaries, fluidly mixing aesthetic choices to create something uniquely theirs.

Of course, the very fact that Straw and Ochello, two gay men described as "old bachelors who shared this room all their lives together," were able to maintain their position within a hierarchical structure is variant from the antebellum model; however, this seeming contradiction to the ethic system of the Old South is tolerated because it does not interfere with the prioritization of white male supremacy- the brotherhood of all white men mentioned by Wyatt-Brown. However, with no wives, it is clear that they will have no heir from their own bloodlines, which results in Big Daddy's eventual inheritance. Although this is certainly not the norm for policies of inheritance, Bibler proposes that homosexuality does not necessarily threaten the plantation system: "While the plantation hierarchies reinforce the white male's social superiority, homosexuality does not simultaneously undermine or destabilize his social position or his masculinity because homosexual desire operates well within that singular pattern of relations that join men to other men as equals" (393). Thus, the homosexuality of Straw and Ochello is tolerated since "a homosexual union between them leaves intact the very hierarchies of race, class, and gender that their love transcends," completely preserving the plantation system (Bibler 394-395). This underscores Wyatt-Brown's ascertainment that the rules that govern this society were indeed mutable and fickle, clearly adding to the superficiality of the system.

However, while their homosexuality could be tolerated because the plantation system prioritized white supremacy and patriarchy, Straw and Ochello still lacked an heir, and, thus, relied on Big Daddy, another white man, to supply them with an alternate source of progeny. Big Daddy's low socioeconomic status was overlooked in favor of the plantation system's continuance, just as Straw and Ochello's homosexuality was overlooked for the same reason. Big Daddy describes how Straw and Ochello took him in when he had nothing: "I had worn my shoes through, hocked my-I hopped off a yellow dog freight car half a mile down the 
road, slept in a wagon of cotton outside the gin-Jack Straw an' Peter Ochello took me in. Hired me to manage this place which grew into this one" (Williams 118-119). He continued to work "in the fields" until he became "overseer," eventually even becoming Ochello's "partner” once Straw died (Williams 79). Thus, he was raised to the level of a socio-economic equal. Big Daddy could accept the homosexuality of Straw and Ochello because of the shared bond of white male privilege which made the three of them, in some way, the same. Thus, the seemingly idyllic and tender world of Straw and Ochello-as well as Big Daddy's claims of tolerance-are complicated by their shared investment in maintaining white male hierarchies. The plantation that raised Brick is a home to contradiction.

Another seeming contradiction to the Antebellum Southern tradition is that Big Daddy, in his own way, modifies the structure of inheritance in an effort to prioritize sameness through preference for his younger son. Initially, the battle between brothers (or, perhaps, between their wives) for the estate hinges on producing offspring, but Big Daddy explains his decision making in another framework in Act Two:

Should I or should I not, if the jig was up, give you this place when I gosince I hate Gooper an' Mae an' know that they hate me, and since all five same monkeys are little Maes an' Goopers.-And I thought, No!-Then I thought, Yes!-I couldn't make up my mind. I hate Gooper and his five same monkeys and that bitch Mae! Why should I turn over twenty-eight thousand acres of the richest land this side of the valley Nile to not my kind?-But why in hell, on the other hand, Brick-should I subsidize a goddam fool on the bottle?-Liked or not liked, well, maybe even-loved--Why should I do that?Subsidize worthless behaviour? Rot? Corruption? (Williams 112)

The struggle can be summed up as a choice between giving the plantation to someone he loves but who is currently unable to coherently think or giving the plantation to someone "not [his] kind" who is responsible. For the sake of the plantation, then, the choice should be clear. However, Big Daddy distances himself from Gooper, even though Gooper is his own blood, with a notion that they are not the same kind. This distancing becomes an obstacle for inheritance because it would be an act against Big Daddy's own honor to give the plantation to someone that he does not respect. Thus, for Big Daddy, sameness and practicality are equal determinants in dictating inheritance. As a result, Big Daddy decides to "wait and see" if Brick stops drinking before making his final decision, unaware of his imminent death (Williams 112). Therefore, the condition placed on Brick, even with the privilege of sameness, is that Brick must stop drinking. In order to care for the plantation, he would have to actively participate, and Brick refuses. "I don't care," he says to his father regarding both his father's dilemma and his own salient future (Williams 112). Big Daddy is trying to prioritize the plantation's success while also dealing with his son's refusal to prioritize the plantation.

Meliora Vol. 1, Issue 1 
While Big Daddy embodies the pressure and incentive that the ethic system of honor places on the inheritance of the family plantation, Maggie, in pressuring Brick to have a child, represents the necessity of children and heterosexual activity in order to keep the family plantation thriving. Within the first three pages of the script, Maggie mentions angrily that Gooper, the oldest Pollitt son, and his family, including his wife and five children, make "constant little remarks and innuendoes about the fact that [Brick] and [Maggie] have not produced any children, are totally childless and therefore totally useless" (Williams 19). Maggie says "useless," meaning that they are useless in the eyes of the plantation system, as, without a child, they cannot guarantee a patriarchal lineage. A child is necessary for the sake of "the estate" more than any interpersonal satisfaction or fulfillment (Williams 20).

However, Maggie has her own goals beyond the sake of merely the plantation itself. She wants to have a child because it will guarantee her social reputation as the wife of an heir to a plantation; she is trying to establish herself within the system of honor that relies on social appearances. Maggie's motivation to have a child with Brick is twofold: she wants to reestablish an intimate connection with Brick, and she wants to have a child with him in order to attain the plantation and financial security. Her concerns can be traced to her own previous socioeconomic status: "I've been so God damn disgustingly poor all my life" (Williams 54). Her fear is mostly for the future: "You can be young without money but you can't be old without it. You've got to be old with money because to be old without it is just too awful, you've got to be one or the other" (Williams 54). While Brick has "given up the struggle," or at least tries his best to, he chastises Maggie for concerning herself over such anxieties as money (Williams 19). Maggie tries to express her deep anxiety about money to Brick by describing herself as a "cat on a hot tin roof... just trying to stay on" (Williams 31). Brick, however, dismisses her, saying "jump off the roof, jump off it," insinuating that her attempts to motivate him to action are futile (Williams 40). Brick has the privilege to ignore her, but Maggie, knowing full well what it is like to live without money, has every reason to desperately care. Struggling to establish herself as honorable in reputation, she recognizes inheritance as a means of guaranteeing her future as socially secure.

Because of the pressure she places on herself to attain this security, she is willing to do anything within the bounds of acceptable social conduct, including telling outright lies, in order to attain her ambitious status. She tells Brick, "I'm not good. I don't know why people have to pretend to be good, nobody's good. The rich or the well-to-do can afford to respect moral patterns, conventional moral patterns, but I could never afford to, yeah, but-I'm honest! Give me credit for just that" (Williams 61). From Maggie's point of view, conventional moral patterns are falsehoods. If conventional morality is equivalent to "true honor" as described by Wyatt-Brown, then Maggie is explicitly recognizing that the code of honor that truly rules the Southern world is not reliant on the goodness and inner harmony innate to 
true honor. In fact, according to Maggie, true honor is an impossibility, and only those with social status can embody even the façade of total goodness.

However, Maggie is determined to change her circumstances, regardless of these ideals' impossibility and her inability to embody them. Maggie can respect herself while going against this true honor because she has fully accepted the necessity of presenting an outward appearance that is contradictory to inner truth. By freeing herself from the confines of true honor, she allows herself to manipulate truth, using her sexuality and femininity as tools to gain social power when she cannot access the homosocial world of the patriarchal plantation. She understands her current circumstances and what she needs to do to change them; she describes herself as "Born poor, raised poor, expect to die poor unless I manage to get us something out of what Big Daddy leaves when he dies of cancer" (Williams 61). Maggie believes that it is up to her to persuade Big Daddy to leave the plantation to Brick. Maggie's untrue announcement that "A child is coming, sired by Brick, and out of Maggie the Cat" is a determined calculation for the purpose of achieving the patrimonial legacy for Brick and herself (Williams 167). She banks on "Big Daddy's dream" to foster sameness through Brick's son, hoping for a "grandson as much like his son as his son is like Big Daddy," hoping that his life-blood will be carried to the next generation regardless of Brick's current inertia (Williams 162). Maggie may not be able to access the homosocial world of white male brotherhood directly, but her ability to foster children is integral for the system of inheritance to be fulfilled. Thus, she takes direct action towards her goal of inheritance by utilizing the very femininity that bars her from Brick's acceptance.

Maggie is able to separate her outward actions from her inner self, freeing herself of the unrealistic expectation to achieve inner harmony between the two. Even though Maggie lies to Big Daddy about his birthday gift-falsely telling him it was from Brick - and announces her own pregnancy, Maggie maintains honesty to herself. Since she does not believe in true Southern honor, she views her trickery not as a moral downfall but as a necessary means to an end: "[I] can't afford t' be thinskinned anymore" (Williams 27). She can separate guilt from shame, willing to be guilty as long as she causes no shame. As she states earlier, goodness is relative based on interwoven and contradictory acts. Therefore, instead of rejecting society and retreating to inaction as Brick does, she willingly works alongside it in order to stay on the hot tin roof. Her honesty relies not on honesty to others, but honesty to the self, knowing herself and accepting herself fully.

Big Daddy says to Brick that "I've lived with mendacity! - Why can't you live with it? Hell, you got to live with it, there's nothing else to live with except mendacity, is there?" to which Brick's only response is "Liquor" (Williams 111). "Liquor is one way out an' death's the other," counters Big Daddy later, emphasizing that pretense, diversity, and complications are part of participating in the Southern social world (Williams 129). Thus, both Maggie and Big Daddy operate in a 
compromised world, both attaining or trying to attain wealth and social status, both willing “to pretend stuff” in order to achieve their goals (Williams 110).

\section{Brick's Loyalty to True Honor}

Brick, however, believes in the antiquated concept of true honor as defined by Wyatt-Brown, and Skipper's death jars him into a confrontation with the unreality of this ideal that causes him inner turmoil and stagnation. Brick's crisis is rooted in an inability to accept that the system of honor that rules the Southern aristocratic system is not true honor but a more complex and contradictory form of honor. He fails to recognize, however, that his ideal of true honor leads to ends just as violent as the self-serving honor of his family.

Brick's privilege as a wealthy white man has afforded him a life of very little compromise. Brick's identity has been stable most of his life, much like his name, for a brick is stable, unmovable, and hardened. Brick imagines himself as stable as a brick because his identity had never been challenged. He is white, a star athlete, and from money; he is definitively privileged, and, thus, in his world, reputable. Because his outer reputation and his inner conception of himself were never at odds in his youth, Brick has never had to question the practicality of true honor. In fact, the social world is in such alignment with Brick's conception of himself that he never had to question the morality it proposed. In a stage direction from Act Two, Williams makes explicit that Brick's position as socially privileged led to an internalization of society's prejudiced attitudes: "In his utterance of [fairies as a slur for gay men], we gange the wide and profound reach of the conventional mores he got from the world that crowned bim with early laurel' (122). Brick demands of himself and his family the "high moral standard" of the Old South that secures his reputation, praises him, and tells him that he is a man of honor. As shown by Brick's anecdotes of his college fraternity's violence against gay men, the conventional mores of Southern society in the 1950s includes homophobia, and thus his homophobia becomes a tenet of the honor code that Brick has adopted. Because he was able to adopt his society's prevalent morality without discomfort, Brick assumes everyone should; everyone can and should strive for true honor. Thus, he hates liars and all those comfortable with incongruences between inner belief and outer action, failing to consider that Southern society is not structured to benefit people who hold different identities than his own.

Big Daddy, in an attempt to reveal the illusory nature of true honor, encourages his son to accept the fact that mendacity is, in fact, integral to the Southern system. Big Daddy recognizes that truth is subjective and encourages his son to consider the truths of others even if they seem contradictory to his own or cause personal discomfort. Brick revolts against this, believing that to accept contradiction would compromise his values by adopting a hypocritical sliding scale 
of virtue. Trying to enable his son to see the truth, Big Daddy accuses Brick of directly causing Skipper's death, as Brick hung up on Skipper when Skipper confessed his romantic feelings for Brick: "You!-dug the grave of your friend and kicked him in it!-before you'd face the truth with him" (Williams 127). Brick's responds, "His truth, not mine," distancing himself from Skipper, as if accepting his friend's homosexuality implies his own (Williams 127). Big Daddy continues, "His truth, okay. But you wouldn't face it with him" (Williams 127). He recognizes that Skipper and Brick are separate and does not address his own son's sexuality, but he also discerns the importance of accepting the code that binds men together, even if that is seemingly contradictory to the "high standards" imposed by social standing. As a result, Big Daddy is sympathetic to the idea that befriending someone with a different identity does not invalidate or reflect upon one's own identity.

While Big Daddy proposes balancing divergent views, Brick is confused about this complexity of subjective truth. In reply, Brick says "Who can face truth? Can you?," exemplifying the heart of his problem: he cannot accept a truth if it challenges his or society's preconceived notions (Williams 127). He is unable to accept Skipper's homosexuality because of his own relationship with societal taboos. Brick is unwilling to reconcile how Skipper's confession might complicate his relationship with himself, as the possibility of being attached, let alone attracted to Skipper in some way, may rupture his own view of himself in relation to his society. The mere possibility that he might be considered adjacent to homosexuality threatens his view of himself as strictly adherent to his rigid and accepted moral code.

In order to avoid contemplating the complexities of the situation, Brick dismisses Skipper's homosexuality as mere momentary confusion by blaming Maggie for planting in Skipper's "mind the dirty, false idea that what [they] were was just a frustrated case of that ole pair of sisters," referencing the gay couple that owned the plantation before Big Daddy (Williams 125). Brick says that "poor Skipper, went to bed with Maggie to prove it wasn't true, and when it didn't work out, he thought it was true" (Williams 125). Wyatt-Brown's interrogation of Southern misogyny might inform how Brick's deep-rooted suspicion of women permits him to blame Maggie for convincing Skipper that their friendship could have ever transformed into something sexual. Therefore, Brick is angry at Maggie, who, from his point of view, insinuated herself between Brick and Skipper, created doubt in Skipper's mind, destroyed the image of the men's relationship, and seeded innuendos of homosexuality within the family. Additionally, when Skipper confessed his love for Brick, the relationship was no longer the ideal of male bonding of camaraderie accepted by the Southern code.

Another part of Brick's confusion and adamant refusal to believe Skipper is Brick's misunderstanding of homosexuality as necessitating a sexual act. Skipper's inability to perform sexually with Maggie is not evidence of homosexuality; instead,

Meliora Vol. 1, Issue 1 
for Brick to accept Skipper's homosexuality, Brick would require the "dirty" act of "sodomy," which is contrary to their "pure an' true" friendship (Williams 119-123). Since it is the act of penetration that dirties the relationship for Brick, the fact that they only "reached[ed] across the space between two beds and shake hands to say goodnight" refutes any implication of homosexuality between the two (Williams 123). Thus, because he and Skipper did not have sex, he believes that neither him nor Skipper can be gay. Being a believer of true honor, he dismisses the possibility of any inner feeling because there was no outer action. Using this rationale, he thinks he can distance himself from accusations of homosexuality that might infringe upon his honor.

This potential crisis of association with homosexuality is not just internally upsetting to Brick. Rather, he knows that if others even think he is gay, his reputation in society and in his family is threatened. Although Brick protests that he does not want to participate in the family, he goes to great lengths to find the source of this damaging lie to his reputation. When Brick interrogates Big Daddy, he is furious that "Gooper and Mae suggested" to Big Daddy that his relationship with Skipper was potentially gay (Williams 116). "I thought that was Maggie's suggestion," he says to his father, which reflects Brick's own embedded fear of his wife's ability to destroy his reputation. He extends this fear to his own father and all of society as he desperately cries, "Who else's suggestion is it, is it yours? How many others thought Skipper and I were-" (Williams 116-117). As Brick aggressively tries to prove himself not gay, his defensiveness is almost potential evidence itself that the accusation speaks some truth. However, to assume his homosexuality with certainty is to do exactly what his family is doing: trying to identify him from outside himself.

The only place where Brick's desire for an honorable reputation and his tender feelings for Skipper can coexist without scrutiny appears to be in the youthful and homosocial world of boyhood. According to Brick, Skipper is straight, and they had a "clean, true thing between" them (Williams 122). He raises their relationship to something "too rare to be normal," believing that "any true thing between two people is too rare to be normal" (Williams 122). For Brick, the only place male feelings can acceptably exist is the "innocence" earlier described by Faulkner when self-reflection is impossible. "Why can't exceptional friendship, real, real, deep, deep friendship! Between two men be respected as something clean and decent," Brick asks, distraught (Williams 122).

What Brick is describing is sometimes found in that chaste and emotional bond between boys often seen in cherished children's literature. According to Leslie Fiedler, books such as Huckleberry Finn, another Southern classic, exemplify this male-male bond as "an essential aspect of American sentimental life: the camaraderie of the locker room and ball park, the good fellowship of the poker game and fishing trip, a kind of passionless passion, at once gross and delicate, homoerotic in the boy's sense, possessing an innocence above suspicion" (Fielder 4). This locker room 
relationship, this bond too pure for homosexuality, is the idealized version of his relationship with Skipper. "To doubt for a moment this innocence," Fielder goes on, "would destroy our stubborn belief in a relationship simple, utterly satisfying, yet immune to lust; physical as the handshake is physical, this side of copulation" (Fielder 4). Mark Royden Winchell, in a response to Fielder, argues that "Tennessee Williams's Cat on a Hot Tin Roof is a scandalous, and ultimately subversive, play precisely because it does doubt the "innocence" of such a relationship" (Winchell 701). Regardless, Brick can only validate the innocent aspects or childhood memories of their relationship because doing so supports his efforts to maintain his honorable reputation and self-worth. Brick is clinging to Fielder's belief that his relationship with Skipper could never be sexualized, but, as Winchell suggests, that assumption is a falsehood that disregards the reality of homosexuality.

Instead of turning inwards, Brick tries to ignore his current reality, longing for a past when these questions of sexuality were never posed. "If Skipper is undone by too much knowledge," Winchell suggests, "Brick suffers from a desperately willed innocence" (Winchell 705). Instead of facing Skipper's truth, that their relationship was, at least on one side, not immune to lust, Brick hangs up on him, drinks, and blames others (Williams 126). When Brick breaks his ankle "on the high school athletic field... Jumpin' hurdles... At two or three in the morning," completely drunk, it is not his immaturity or arrested development that leads him back to his high school track field. Instead, he is drawn to the lost world where a boy's love was accepted as intimate without suspicion (Williams 21). Indeed, this world in which Brick found fulfillment and self-worth as a respected member of the society and family is now lost to him, symbolized by his broken ankle and inability to "clear the first hurdle" (William 21). This attempt to return symbolically to his childhood was unsuccessful, and it has left him hobbled and unable to understand himself and his family. His social system no longer makes sense, as he has lost the stability of his connection to his own identity that he once had in his youth.

While it may be the external world with which Brick struggles, it is the internal world with which Brick refuses to engage. Instead of being self-reflective regarding these accusations, Brick turns to drinking, a means to avoid social interaction, as it is his social reputation that is at risk. Drinking provides him with what he calls "the click I get in my head when I've had enough of this stuff to make me peaceful" (Williams 33). He tells Big Daddy that "it don't happen except when I'm alone or talking to no one," meaning that he has to completely remove himself from the social world in order to find peace (Williams 102). If he is completely alone, then no one can interpret his actions and attempt to identify him. His reaction to these external interpretations of him does not lead to introspection or self-scrutiny, but rather to dazed inaction. Brick "started drinking when [his] friend Skipper died" (Williams 115). Big Daddy suggests that this response parallels Peter Ochello's reaction to the death of his partner (Williams 115). However, Brick's drinking is not 
necessarily evidence of Brick's homosexual love for Skipper. Rather, Brick would prefer to be labeled an alcoholic over a homosexual, as he thinks the former more socially acceptable. Although Skipper's homosexuality triggers Brick's crisis because of a potential threat to his reputation, Brick's potential homosexuality remains unclear. Do his protests indicate that he might be gay? Is he just mad at Skipper for being gay? Is he confused because he blatantly hates gay people but loved Skipper? Is he wrestling with the guilt that his homophobia caused the death of his friend? Whatever the cause, Brick's fear of the potential loss of his honorable reputation cannot be underestimated. For Brick, because being gay would sully his reputation, he is so concerned with shutting down accusations of his homosexuality that he does not take time to assess his own inner feelings as potentially separate from his reputation.

While underneath the crisis of Brick's reputation there may very well be a crisis of sexual identity, Williams is careful to steer his audiences away from what he considers " "pat' conclusions," or easy answers, such as labelling Brick's sexuality as the core of the crisis (Williams 116). Instead, Brick is tied to the self-deception and repression inbred into the moral fiber of a system of mendacity, contradiction, and shame and, thus, is unavoidably fiercely dependent on reputation. In a lengthy stage direction in Act Two, Williams elaborates on Brick's inner psyche, or, at least, why he refuses to do so completely:

The fact that if [an inadmissible thing] existed [between Brick and Skipper] it had to be disavowed to 'keep face' in the world they lived in, may be at the heart of the 'mendacity' that Brick drinks to kill his disgust with. It may be the root of his collapse. Or maybe it is only a single manifestation of it, not even the most important... Some mystery should be left in the revelation of character in a play, just as a great deal of mystery is always left in the revelation of character in life, even in one's own character to bimself. (Williams 116-117)

Brick cannot reconcile that, in order to maintain an honorable reputation, or "keep face" lying is inevitable. He desires total congruency between inner truth and outer action. Therefore, when Skipper reveals his truth to Brick, Brick is fearful not of Skipper's sexuality or even the potential complication of his own so much as the social implications of being associated with homosexuality. In order to maintain his loyalty to true honor, Brick cannot distinguish between inner belief and outward action. Thus, he does not know how to accept Skipper into his life once he has outed himself while maintaining his own spotless reputation. Brick must choose to either abandon his system of true honor or he must abandon his friend. He chooses the latter, directly causing his friend's death through this rejection. As Williams makes clear in this stage direction, the true complexity of Brick's grief is unknown, perhaps even to himself. However, the result is undeniable: Skipper is dead.

The tragic irony of this choice is that, in choosing to stay loyal to his moral code, Brick proves its limitation; although Brick's moral code relies on absolute 
truthfulness to avoid secrets and public shame, in choosing his moral code over his friend, he represses the truth and creates his own shame. Unable to recognize this tragedy in full and move forward, either by accepting painful contradiction as Maggie does, or by rejecting the contradictory Southern honor code altogether, he refuses to acknowledge the truth of the situation, even going so far as to create a fiction that Skipper is not truly gay. Thus, in trying to uphold the façade of true honor, Brick himself becomes what he despises: a liar. In this way, he is no better than his father or his wife-he perpetuates a system of mendacity.

By being unwilling to accept the truth of the situation, he is not only hurting himself but contributing to and perpetuating a larger and more violent ignorance. The reader can never know Skipper's full truth because Brick refused to listen to it; in doing so, he silences the only voice that could speak directly to the experience of homosexuality within this group of people. No one in the play knows how to grasp this kind of love between men, so they turn it into metaphors, failing to grasp the full truth of it. Big Daddy, describing how Peter Ochello stopped eating after the death of Jack Straw, compares their relationship to a dog and his master: "When Jack Straw died-why, old Peter Ochello quit eatin' like a dog does when its master's dead, and died, too" (Williams 119). Big Daddy claims to "understand such" things as this relationship, but he dares not call it love (Williams 119). The devotion between these two men is so strong that one cannot live without the other, but Big Daddy cannot describe it using the vocabulary that is reserved for heterosexual relationships. Maggie, the other character in the play that reaches a sort of imperfect tolerance of homosexuality, likens Skipper and Brick to "Greek legends" raising them above the dirtiness of the sex act in order to name their love "clean" (Williams 58). She does call it love, but "love that could never be carried through to anything satisfying or even talked about plainly" (Williams 58). Even she cannot conceptualize a reconciliation of Southern society's ethics and fully accepted homosexuality. Thus, homosexuality exists merely as a theoretical idea to the entire Pollitt family; all three characters that could perhaps speak truth to it are dead by the play's beginning.

While Maggie and Big Daddy, a liar and a relativist respectively, are not necessarily truthful, Brick is not as perfectly truthful as he claims. Perhaps he does not lie outright, but, as he refused to listen to Skipper's truth, it can be said that he does not value truth in, of, or for itself. While Big Daddy and Maggie actively succeed in enhancing their social position within the Southern aristocracy, and, thus, perpetuate its violence, Brick's passive complacency contributes to the system's selfdestructive dismissal of truth, reflecting its penchant for mendacity. Thus, through all of its characters' decisions to obey their own definitions of honor, the oppressive Southern plantation system of $A$ Cat on a Hot Tin Roof continues its slow, festering march towards decay. 


\section{WORKS CITED}

Bibler, Michael P. “'A Tenderness Which Was Uncommon': Homosexuality, Narrative, and the Southern Plantation in Tennessee Williams's 'Cat on a Hot Tin Roof." The Mississippi Quarterly, vol. 55, no. 3, Mississippi State University, 2002, pp. 381-400.

Fiedler, Leslie. "Come Back to The Raft Agin, Huck Honey!." The Fiedler Reader by Briar cliff Manor, New York: Stein 8c Day, 1977, pp. 4-6.

Williams, Tennessee. Cat on a Hot Tin Roof. New Directions, 2004.

Winchell, Mark Royden. "Come Back to the Locker Room Ag'in, Brick Honey!" The Mississippi Quarterly, vol. 48, no. 4, Mississippi State University, 1995, pp. 70112.

Wyatt-Brown, Bertram. Southern Honor: Ethics and Behavior in the Old South. Vol. 25th anniversary ed, Oxford University Press, 2007. EBSCOhost, search.ebscohost.com/login.aspx?direct $=$ true $\& d b=$ nlebk $\& A N=209631 \&$ site $=$ ehost-live $\&$ scope $=$ site.

\section{EXTENDED BIBLIOGRAPHY}

Als, Hilton. "The Man Who Queered Broadway." The New Yorker, https://www.newyorker.com/books/page-turner/man-queered-broadway. Accessed 9 Nov. 2020.

Ambiguity and Performance in the Plays of Tennessee Williams on JSTOR. https://wwwjstor-

org.ezproxy.cul.columbia.edu/stable/26475766?Search=yes\&resultItemClick $=$ true\&searchText $=\% 22$ Ambiguity + and + Performance + in + the + Plays + of + Tennessee+Williams. $\% 22$ \&searchUri $=\% 2$ Faction $\% 2 \mathrm{FdoBasicSearch} \% 3 \mathrm{FQu}$ ery $\% 3$ DAmbiguity $\% 2$ Band $\% 2$ BPerformance $\% 2$ Bin $\% 2$ Bthe $\% 2$ BPlays $\% 2$ Bof $\% 2 \mathrm{BTennessee} \% 2 \mathrm{BW}$ illiams. $\% 25 \mathrm{E} 2 \% 2580 \% 259 \mathrm{D} \& \mathrm{ab} \_$segments $=0 \% 2 \mathrm{Fbas}$ ic_search_solr_cloud $\% 2$ Fcontrol\&refreqid $=$ fastlydefault \%3Af824325884f3fe9a63ad971d83827a3f\&seq=1\#metadata_info_tab _contents. Accessed 9 Nov. 2020.

Bak, John S. "Sneakin' and Spyin" from Broadway to the Beltway: Cold War Masculinity, Brick, and Homosexual Existentialism." Theatre Journal, vol. 56, no. 2, Johns Hopkins University Press, 2004, pp. 225-49.

Bibler, Michael P. “'A Tenderness Which Was Uncommon': Homosexuality, Narrative, and the Southern Plantation in Tennessee Williams's 'Cat on a Hot Tin Roof." The Mississippi Quarterly, vol. 55, no. 3, Mississippi State University, 2002, pp. 381-400.

Brantley, Ben. "A Storm From the South, Brewing in a Bedroom (Published 2013)." The New York Times, 18 Jan. 2013. NYTimes.com, 
https://www.nytimes.com/2013/01/18/theater/reviews/cat-on-a-hot-tinroof-at-richard-rodgers-theater.html.

Buscombe, Edward. "Code Violations." Film Quarterly, vol. 65, no. 2, University of California Press, 2011, pp. 86-87. JSTOR, doi:10.1525/fq.2011.65.2.86.

Cat on a Hot Tin Roof. video-alexanderstreet-com.ezproxy.cul.columbia.edu, https://videoalexanderstreet-com.ezproxy.cul.columbia.edu/watch/cat-on-a-hot-tin-roof. Accessed 9 Nov. 2020.---. p. 166.

Cat on a Hot Tin Roof - Theater - Review - The New York Times. https://www.nytimes.com/2008/03/07/theater/reviews/07roof.html.

Accessed 9 Nov. 2020.

“Cat's Meow! How Tennessee Williams' Cat on a Hot Tin Roof Keeps Prowling Back to Broadway." Broadway.Com, https://www.broadway.com/buzz/166691/cats-meow-how-tennesseewilliams-cat-on-a-hot-tin-roof-keeps-prowling-back-to-broadway/. Accessed 9 Nov. 2020.

Colanzi, Rita. "Caged Birds: Bad Faith in Tennessee Williams's Drama." Modern Drama, vol. 35 no. 3, 1992, p. 451-465. Project MUSE, doi:10.1353/mdr.1992.0008.

Fiedler, Leslie. "Come Back to The Raft Agin, Huck Honey!." The Fiedler Reader by Briar cliff Manor, New York: Stein 8c Day, 1977, pp. 5-6.

Hancock, David. "The Currency of Desire: Libidinal Economy, Psychoanalysis, and Sexual Revolution, by David Bennett." Journal of Cultural Economy, vol. 10, no. 5, Routledge, Sept. 2017, pp. 479-81. Taylor and Francis+NEJM, doi:10.1080/17530350.2017.1335224.

Hornby, Richard. “Southern Decadence.” The Hudson Review, vol. 57, no. 1, Hudson Review, Inc, 2004, pp. 111-17. JSTOR, doi:10.2307/4151389.

Hume, Robert D. "Gothic versus Romantic: A Revaluation of the Gothic Novel." PMLA, vol. 84, no. 2, Modern Language Association, 1969, pp. 282-90. JSTOR, doi:10.2307/1261285.

King, Kimball. “Tennessee Williams: A Southern Writer." The Mississippi Quarterly, vol. 48, no. 4, Mississippi State University, 1995, pp. 627-47.

Kinsey, Alfred C., et al. "Sexual Behavior in the Human Male." American Journal of Public Health, vol. 93, no. 6, June 2003, pp. 894-98.

Parker, Brian. "A Preliminary Stemma for Drafts and Revisions of Tennessee Williams's 'Cat on a Hot Tin Roof (1955)." The Papers of the Bibliographical Society of America, vol. 90, no. 4, [University of Chicago Press, Bibliographical Society of America], 1996, pp. 475-96.

"Postwar Gender Roles and Women in American Politics." US House of Representatives: History, Art \& Archives, U.S. Government Printing Office, 2007, history.house.gov/Exhibitions-and-Publications/WIC/HistoricalEssays/Changing-Guard/Identity/.

Meliora Vol. 1, Issue 1 
Pugh, Tison. "Camp Sadomasochism in Tennessee Williams's Plays.” Texas Studies in Literature and Language, vol. 58, no. 1, University of Texas Press, 2016, pp. 2044.

---. Queering the South on Screen. University of Georgia Press, 2020. JSTOR, doi: $10.2307 /$ j.ctvqmp3k4.

Roudané Matthew C. The Cambridge Companion to Tennessee Williams. Cambridge University Press, 2006.

"Southern Belles and Ladies." History Engine: Tools for Collaborative Education and Research University of Richmond, historyengine.richmond.edu/episodes/view/2259.

Sartre, Jean-Paul. Being and Nothingness: An Essay on Phenomenological Ontology. Translated by Hazel E. Barnes, New York, 1956.

Williams, Tennessee. Cat on a Hot Tin Roof. New Directions, 2004.

Winchell, Mark Royden. "Come Back to the Locker Room Ag'in, Brick Honey!" The Mississippi Quarterly, vol. 48, no. 4, Mississippi State University, 1995, pp. 70112.

Woodman, Harold D. "Economic Reconstruction and the Rise of the New South, 1865-1900." Interpreting Southern History: Historiographical Essays in Honor of Sanford W. Higginbotham, by John B. Boles and Sanford W. Higginbotham, Louisiana State Univ. Press, 1995, pp. 254-307.

Wyatt-Brown, Bertram. Southern Honor: Ethics and Behavior in the Old South. Vol. 25th anniversary ed, Oxford University Press, 2007. EBSCOhost, search.ebscohost.com $/$ login.aspx?direct $=$ true\&db=nlebk\&AN $=209631 \&$ site $=$ ehost-live\&scope $=$ site.

CATHERINE FERRANTE, Barnard College '21, is pursuing a BA in English with a concentration in theatre. They are passionate about the intersection between the spiritual and the artistic, the psychological aspects of character, and the process of creating safe and positive theatre spaces. After graduation, they plan to gain professional experience before pursuing an MFA in Directing. 